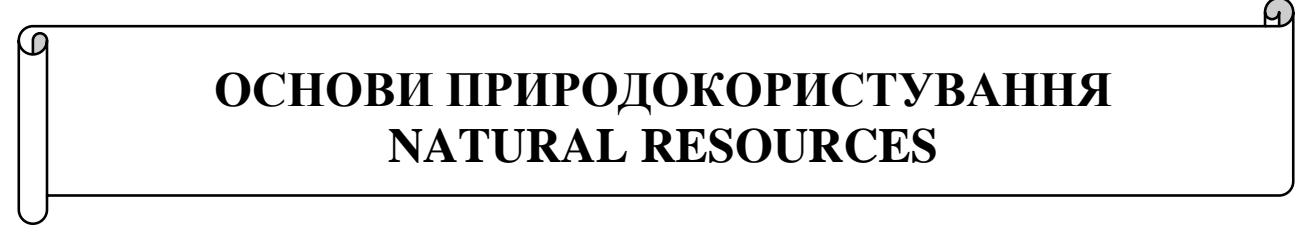

UDK 049.3:574.4:581.526

Sergii I. Azarov ${ }^{1}$, D. S., Senior Research Associate

ORCID ID 0000-0002-9951-8867 e-mail: azarov@kinr.kiev.ua

Oleksii S. Zadunaj ${ }^{2}$, Head of the Center, Postgraduate

ORCID ID 0000-0001-8589-1604 e-mail: a.zadunaj@ gmail.com

${ }^{1}$ Institute for Nuclear Research of NASU, Kyiv, Ukraine

${ }^{2}$ State Research Institute of Special Communications and Information Protection, Kyiv, Ukraine

\title{
ANALYSIS OF THE STABILITY OF WATER BODIES TO THE ACTION OF DESTABILIZING FACTORS
}

\begin{abstract}
Methodical approaches to the assessment of ecological safety of ecosystems based on the establishment of a comprehensive indicator of the degradation of environmental components have been developed, which will allow us to assess non-additive properties of different-scale aquatic ecosystems. The analysis of methods for assessing the stability of water bodies to change the parameters of natural and anthropogenic regimes is carried out. Investigation of the nature of resistance of water bodies has revealed not only their desire for balance, but also a complex fight against regular and irregular (fluctuations) forces. Keywords: ecosystem; ecosystem safety; stability; anthropogenic impacts; properties; parameters; environment; entropy.
\end{abstract}

\section{Introduction}

Today, we meet various global ecological problems such as the formation of ozone holes, the elimination of forests, the formation of deserts, the lack of clean water, the appearance of greenhouse effect, the reduction of species of animals and plants). One of the central issues among them is the problem of environmental safety of water bodies (lakes, rivers, reservoirs and seas). In the practice of modern nature management, we do not have the single general method to assess of the non-additive properties of ecological systems: stability, environmental well-being of reservoirs, etc. It makes us seek for techniques and develop the methods for evaluation the nonadditive properties of the complex systems in nature and society.

(C) S.I. Azarov, O.S. Zadunaj, 2018 
At the end of the 1960s - the beginning of the 1970s the scientific community got interested in the assessment of the stability and variability of natural ecosystems, the ecological well-being of ecosystems at the different levels of the hierarchy, their sensitivity to external impacts.

On the one hand, it can be explained by the successes, achieved by the classical ecology and the rapid development of mathematical ecology. On the other hand we can highlight it by the need for quantitative estimates of man-caused loads on ecosystems, which lead to an «ecological catastrophe». The latter means the destruction of the ecosystem. In addition, we can determine it by the search for nonadditive criteria to assess the properties of natural and anthropogenic-transformed complex systems.

Taking into account the above-mentioned, there is a lack of research on the assessment of non-additive properties of various scales of aquatic ecosystems and the need to zone territories and aquatories by the degree of vulnerability to external man-caused impacts.

\section{Purpose of Research}

The purpose of the research is to analyse the methods to assess the stability water bodies to change the parameters of natural and anthropogenic regimes.

\section{Results of Research}

Stability is a fundamental concept of the ecological systems theory [1]. We use it to find out the maximum permissible level of human intervention in the natural environment.

The stability of aquatic ecosystems means their ability to change under the influence of external factor and to return to their original state after them. There are several properties of this complex phenomenon. So, aquatic ecosystems have different resistance to various types of influence. The single ecosystem can be resistant to one type of violations and unstable to others at the same time. The important property is the emergentism of the stability. Thus, the stability of individual components does not ensure the stability of the entire ecosystem as a whole, but the stability of the ecosystem is always higher than the stability of its subsystems or components.

Thus, the stability of the water body to change the parameters of the regimes is its ability to maintain its properties and parameters of the regime in the conditions of external and internal loads. Therefore, the bodies, which are not able to save their specified properties at the certain time interval of their functioning, are vulnerable to changing the regime's parameters.

There are two methodological approaches to the definition of the concept «stability» in the environmental literature. They differ. The first approach defines stability as the ability of the ecosystem to exist for a long time, saving its basic properties either in a constant environment or in the environment, which changes are not taken into account by the researcher. The second one explains the stability as the ability of the ecosystem to withstand external influences, retaining its properties.

Regarding the above-mentioned, the scientists assess the following properties [2]:

- inertia of the system means the ability of the ecosystem to save the initial state for some time under the influence of external impacts; 
- plasticity of the system means the ability of the ecosystem to move from one state of equilibrium to another, retaining internal connections;

- restoration of a system means the ability of the ecosystem to return to its original state after temporary external influences.

The technique of the assessing the stability of water bodies is associated with solving the problem of quantitative description of many processes that determine the properties of ecosystems and the ability of systems to keep these properties unchanged, or to return to the original state after losing it for a while.

The assessment of the stability to the change in the properties of the natural system is not limited only by one property. It is obtained as a result of taking into account many properties, characterized by a large set of evaluation parameters. The physical-geographical and climatic conditions and the nature of anthropogenic influence are key among them. It should also be noted that the stability of aquatic ecosystems of the cyclic (lakes, slightly flowed reservoirs, ponds) and transit (rivers, highly flowing reservoirs) types is determined by the different natural mechanisms. The stability of the first type is called «adaptive», whereas the stability of the second type is «regenerative». In the first case, the most important property of the natural system is its ability to maintain its original state or smoothly transform into another state, preserving internal links (inertia, plasticity). However, in the second case, the ability of the system to restore its properties many times, to return to the initial state after temporary external influence (recovery) plays the leading role. In addition, the abiotic and biotic components of the ecosystem also differ in their mechanisms of stability. The stability of the abiotic components is achieved by physical-mechanical and chemical processes of transferring, dilution, sorption, migration of matter. The stability of the biotic ones is determined by the ability of the adaptation of organisms to influence, caused by the internal resistance of the biochemical organization as well as the ability to biochemical decomposition of toxic compounds and changes in the specific rates of metabolic processes in the ecosystem under the influence of their actions.

The development of the technique of the assessing stability of aquatic ecosystems of the cyclic type is carried out according to the type of adaptive stability, whereas the watercourses and transit aquatic ecosystems is based on the type of regeneration. Researching the patterns of the influence of environmental factors on hydrobionts, it is very important to choose the optimal criteria for the stability of the communities, which should be the basis of the method of its quantitative assessment. Today, within the framework of the above-mentioned concepts of stability, the scientists distinguish its various features, whereas the gradations and the assessment scales of stability are little researched in the Ukrainian and foreign literature. The scholars often apply quantitative characteristics of various forms of stability, which are based on integral indicators of abundance (traditionally - biomass, the number of organisms in the community or biota as a whole, and rarely - the energy indicators). Formally, we can evaluate all forms of stability according to this principle, whereas the stability of the ecosystem, considered without any impact on it, can be analysed only by the degree of constancy of these quantitative characteristics. Obviously, it is not enough. With this basis, it is impossible to obtain environmentally determined norms, regulate and predict any impacts.

Assessing the sustainability of aquatic ecosystems, we get a problem of finding right criteria. We can use a thermodynamic (entropy) concept of stability as one of the approaches. Besides the spatial-temporal structure, the aquatic ecosystem is 
thermodynamic. The structure, functions and evolution of the aquatic ecosystem depend on the exchange of matter and energy with the environment, as well as on the relationships among processes that increase or decrease the entropy within the ecosystem [3]. This approach to the assessment of environmental sustainability is based on non-equilibrium thermodynamics. We can choose I. Prihozhin's position as a basic principle [4]. According to it, the states, corresponded to the minimum entropy production in linear non-equilibrium thermodynamics, are automatically stable. If we influence the ecosystem by the perturbation, the entropy production will increase. However, the system will respond by returning to the state with the least entropy production. The limit of the perturbation characterizes the magnitude of the stability of the aquatic ecosystem and the level of its self-organization. With the probability of the development of the process in different directions, which are allowed by the principles of thermodynamics, we can see the realization of the factor that provides a minimum of energy dissipation. So the natural evolutionary development of the aquatic ecosystem is always aimed at reducing the growth of entropy that maintains its environmental sustainability [5]. The process of selforganization begins in the cases of the changing one or more control (bifurcation) parameters, and exceeding certain limits of stability. Thus, the aquatic ecosystem transforms into a new state [6]. Here it becomes stable again. Thus, the aquatic ecosystem that develops in the direction of lowering entropy through its passage or decline in production, is more resistant to external influences.

All processes, which contribute to the growth of the ecosystem's order (condensation, polymerization, compression, crystallization, coagulation, differentiation, or another process, which leads to the decrease of the number of states of matter), are accompanied by a decrease in entropy. Entropy increases with the enlargement of the number of particles and states (dissolution, dissociation, evaporation, peptization, erosion). Depending on the combination of the influence of external and internal factors, the ecosystem can be at different stages of growth, instability and survival. According to the theory of I. Prihozhin [7] the order is formed in a non-equilibrium system of chaos. During this process, the energy of the system dissipates and the so-called dissipative structure spontaneously arises. The dissipation means the decrease in energy in the system and the increase its entropy by itself. However, in non-equilibrium conditions, the energy losses are offset by its external influx, which contributes to the self-organization of the system. It needs prevent the system from equilibrium, which is possible only when it exchanges the material-energy flows with the environment. It is sensitive to external perturbations. Given the non-linearity of the processes, small external perturbations can get stronger and generate large-scale changes in ecosystems [8]. If we denote energy by $-\varepsilon$, the entropy of the ecosystem by $-\eta$, and the lower index for variation $(\delta)$ is the amount, which, in this case, does not change - energy $(\varepsilon)$, the equilibrium criterion will be written as: $(\delta \eta) \varepsilon \leq 0$.

It means that for all possible changes in the state of the isolated ecosystem with its constant energy, the variation in the entropy of an equilibrium ecosystem is zero or negative.

To distinguish the types of equilibrium with respect to their stability, we take into account the absolute values of variations (signature by the symbol $\Delta$ ) that do not neglect infinitely small higher orders.

Then the necessary and sufficient conditions for different types of the ecosystem's equilibrium are formulated in a such a way [9]: 
- for stable equilibrium: $(\Delta \eta) \varepsilon<0$;

- for the indifferent equilibrium, there are changes in the state of the ecosystem, for which $(\Delta \eta) \varepsilon=0$;

- In the case of the unstable equilibrium, there are changes in the state of the ecosystem, for which $(\Delta \eta) \varepsilon>0$.

It is quite clear the ecosystem is always in equilibrium if it has the maximum entropy for this energy. In this case, the ecosystem may have several equilibrium states. The state, which corresponds to the highest of the maximum of entropy, has absolute stability.

With anthropogenic pollution of the aquatic environment, the extent of the maximum permissible impact is the volume of pollutants, which can assimilate the ecosystem. Two groups of the mechanisms of the sustainability determine the assimilation capacity. The first one includes the destruction (transformation) and the disposal of pollutants, which lead to their removal from the geochemical cycle. The second group combines the processes of removal outside of this aquatic ecosystem and the conservation (temporary burial) of toxic substances.

The first step in assessing the stability of the aquatic environment to technogenic pollution is to find out the main features that determine the assimilation capacity and balance of entropy. There is some limit significance of man-caused impacts on water bodies. If the system achieves them, it corresponds to a sharp deterioration of the state of the aquatic ecosystem. Thus, the ecosystem loses its stability. Let's imagine that there are perturbations, caused by pollution, in an aquatic ecosystem. It can make the ecosystem be instability. So, we should evaluate the risk of the transformation of the aquatic ecosystem into the state of instability during the period of time. In this case, the risk of instability is the probability of the transition of the aquatic ecosystem from one point of the phase space, where it is at an initial point of time, to the critical area of the space, where the ecosystem becomes unstable. The given model is used to analyse different scenarios and evaluate the probability of transition of the aquatic ecosystem to unstable states.

The numerical significance of the probability characterizes the «risk» of the aquatic ecosystem to become unstable. Recently, the specialists in the theory of stability has been using synergistic ideas about the order and chaos [10].

We can see sudden and cut transitions in the behaviour of the ecosystem, when it reaches the points of bifurcation. There we can highlight the choice of the group of possible trajectories under the influence of small shift of parameters. Such trajectories are unpredictable radically change the pattern of the behaviour of the system. Therefore, the bifurcation is the qualitatively new behaviour of the ecosystem with the small change in its parameters. The example of it can be the evolution of the ecosystem with the development of the trajectory of its movement. In the context of the theory of ecosystem development, we can see rather strange combination of different stages in the process of changing ecosystems, where slow and fast, smooth and sharp phases converge. That is why the subject of the study of synergetics is the significance of the parameters of the system, which determine its bifurcation and self-organization in the new complex structures. In this case, the bifurcation phenomena are always considered by the catastrophe theory, which studies the radical rearrangements of the ecosystem in the process of slow, smooth and small changes in its parameters.

In such ecosystem the scientists distinguish two types of the instability - dynamic and static. The dynamic instability (the effect of «galloping») leads to the chaos and 
the complete destruction of the system. To prevent it we should conduct structural changes in it. The static instability is characterized by the jump transition from one equilibrium state of the ecosystem to another (static bifurcation).

We can observe the static instability in ecosystems with a significant and prolonged deviation of two or more variables змінних from optimal ratios. In the catastrophe theory [11] the bifurcation of the state of equilibrium and the involuntary process make the stability be non-equilibrium, caused by the change in the parameter of the ecosystem. With the approximation of the parameter to the bifurcation value, the ecosystem loses the state of equilibrium, going to other equilibrium states or creating the new pair of states of equilibrium. Moreover one of the equilibrium states is stable, another is unstable.

In the catastrophe theory scientists use the ordinary differential equations, applying so-called «strange attractors», which concern the thresholds of stability and «bifurcation points». So, they are associated with the concept of the stability. The peculiarity of the approach is the fact that in the «points of bifurcation» the dynamic system becomes unstable regarding to fluctuations. The transition through the bifurcation point can be considered as the accidental process that can be compared to flipping a coin. Randomness (chaos), in some extent, always governs the dynamics of ecosystems. The role of chaos at bifurcation points is quite significant. At bifurcation points or at critical threshold points, the behaviour of the ecosystem becomes unstable and can evolve into several alternatives corresponding to different steady modes. In this case, we can only deal with opportunities, and nothing will allow us to predict what kind of mode the ecosystem will choose. The simplest bifurcation point corresponds to a situation where a stable state becomes unstable, whereas two other possible stable states arise symmetrically. The scenario of the loss of a stable equilibrium state involves two possible variants that differ in the phase portrait (space of states) of the ecosystem. The first one is the degeneration of the equilibrium position into the limit cycle that means the transition of the state of equilibrium from stable to unstable (Fig. 1, Upper row). The second option is the situation of unstable equilibrium and the ecosystem becomes unstable (Fig. 1, Lower row).
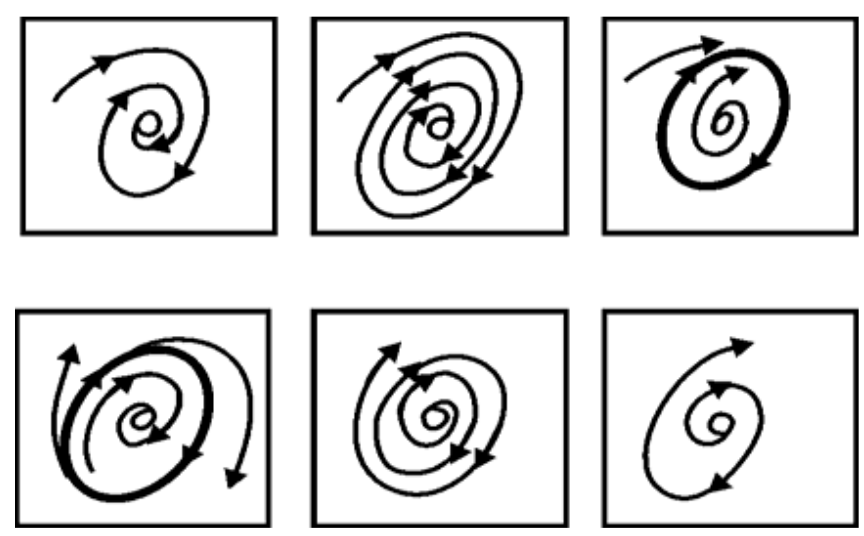

Fig. 1 - Phase portrait of an ecosystem during the loosing of the stability

The first variant is characterized by the slowed-down «swinging» system to its quasi-equilibrium state, which moves from stable to unstable. Such a smooth loss of stability of the equilibrium of the ecosystem will be called soft. We can see it in the nature of the change in equilibrium position by oscillatory periodic processes (Fig. 2) 


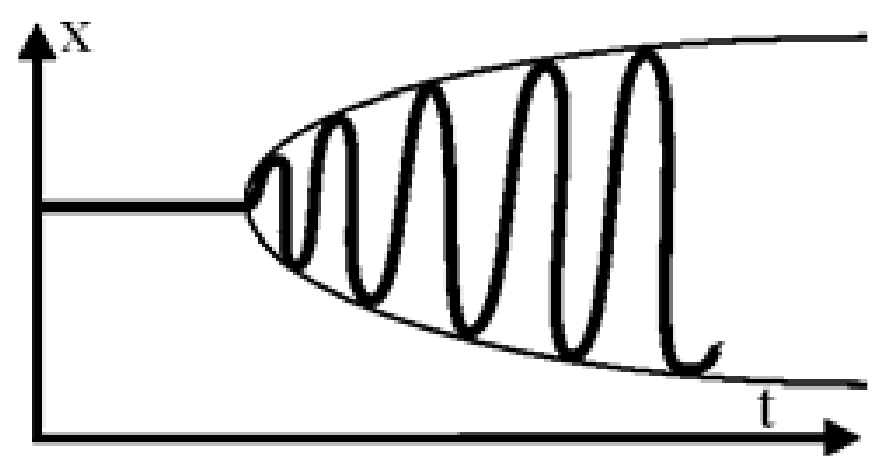

Fig. 2 - Soft loss of the stability of the ecosystem's equilibrium state

Comparing to the first one, the second variant is inherent to the more unstable ecosystem within the high-risk zone. The system with the destructive dynamics deforms and its quasi-equilibrium becomes unstable. The sharp loss of stability of equilibrium is called rigid, which corresponds to a jump-like transition of the ecosystem from stationary behaviour to another mode (Fig. 3).

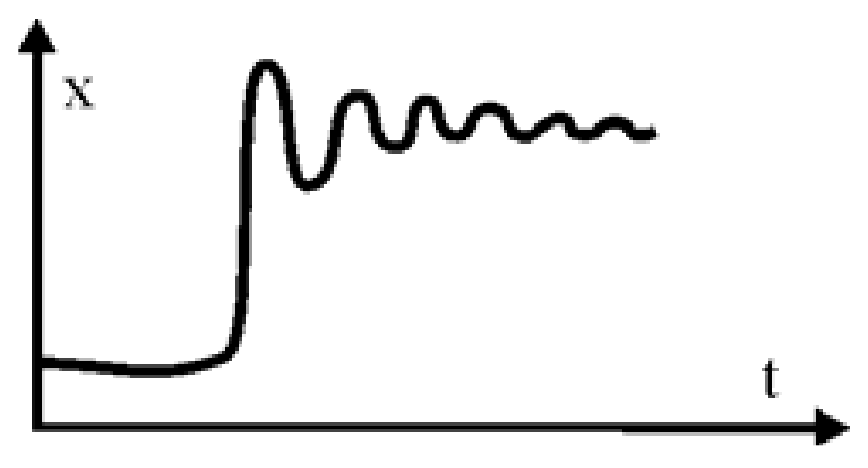

Fig. 3 - Rigid loss of stability of the equilibrium state of the ecosystem

However, in the future the regime, which occupies the ecosystem, may be far from equilibrium or oscillating with a strict period. Therefore it is called the strange attractor (attraction - attracting a lot of phase space) that can be represented by phase divergent, which are curving (Fig. 4).

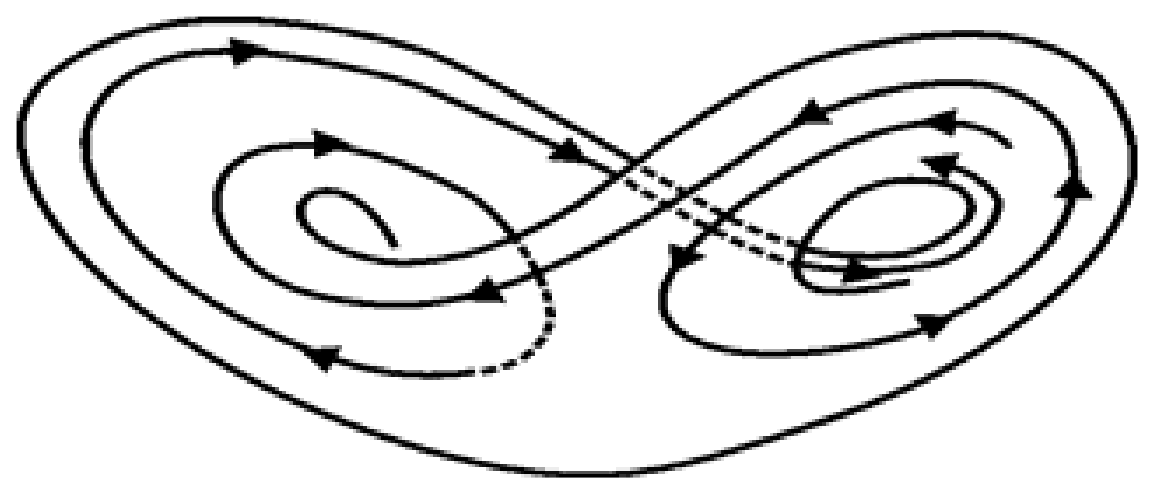

Fig. 4 - Chaotic attractor 
Such a process is the dynamic chaos. So it is the non-periodic movement in the deterministic system. The process of transition from the stable equilibrium to a strange attractor can take place both in hard and soft loss of stability, whereas the cycle, which occurs in the second case, loses stability. These non-periodic variations are sensitive to little changes in initial conditions. Maintaining the stability of the averaged characteristics, they reflect the turbulent behaviour of the ecosystem.

\section{Conclusions}

Thus, the stability of the aquatic ecosystem is the relative invariance of its properties, which can be observed under the influence of permissible perturbations: the ability of the ecosystem to remain within certain limits, despite the interference with perturbations, provided by the task. At the same time, depending on the field of initial perturbations, the scientists distinguish such types of the stability as «in small», «in large» and «in general». According to the nature of the coincidence of the perturbed state to the unsolvable, we can say about the usual and asymptotic stability. The research of the nature of the water bodies' stability has found out their desire for equilibrium as well as the complex fight between regular and irregular (fluctuations) forces, which makes the achievement of equilibrium in real conditions complicated. Under the influence of perturbations, the chaotic state of the aquatic ecosystem can undergo restructuring, when the choice of its steady state depends on the transition process at moments of the bifurcation.

\section{REFERENCES (TRANSLATED AND TRANSLITERATED)}

1. Grodzyns'kyj M.D. Stijkist' geosystem do antropogennyh navantazhen' / M.D. Grodzyns'kyj. - K.: Likej, 1995. - 233 c. (in Ukrainian)

2. Stijkist' ekosystem do radiacijnyh navantazhen' / I.V. Matvejeva, S.I. Azarov, Ju.O. Kutlahmedov, O.V. Harlamova. - K.: NAU, 2016. - 396 s. (in Ukrainian)

3. Strashkraba M., Gnauk A. Presnovodnye jekosistemy. Matematicheskoe modelirovanie. Per. s angl. M.: Mir, 1989. - 376 s. (in Russian)

4. Prigozhin I. Ot sushhestvujushhego k voznikajushhemu. Per. s angl. / Pod red. Ju.L. Klimantovicha. - M.: Nauka, 1985. - 328 s. (in Russian)

5. Prigozhin I. Poznanie slozhnogo. Vvedenie / G. Nikolis, I. Prigozhin : per. s angl. 2-izd., ster. - M. : Editorial URSS, 2003. - 344 s. (in Russian)

6. Prigozhin I., Stengers I. Porjadok iz haosa (Novyj dialog cheloveka s prirodoj). - M.: izd-vo «Editorial URSS», 2003. - 310 s. (in Russian)

7. Prigozhin, I. Vremja, haos, kvant : per. s angl. / I. Prigozhin, I. Stengers. - M.: Izdatel'skaja gruppa «Progress», 1999. - 268 s. (in Russian)

8. Haken G. Sinergetika. Per. s angl. / Pod red. Ju.L. Klimantovicha, S.M. Osovca. M.: Mir, 1980. - 404 s. (in Russian)

9. Haken G. Sinergetika: Ierarhija neustojchivostej v samoorganizujushhihsja sistemah i ustrojstvah : per. s angl. / G. Haken. - M. : Mir, 1985. - 423 s. (in Russian)

10. Vladimirov V.A. Upravlenie riskom: Risk. Ustojchivoe razvitie. Sinergetika / V.A. Vladimirov, Ju.L. Vorob'ev, S.S. Salov i dr. - M. : Nauka, 2000. - 431 s. (in Russian) 11. Arnol'd V.I. Teorija katastrof / V.I. Arnol'd. - 3-e izd., dop. - M. : Nauka, 1990. - 128 s. (in Russian) 


\section{REFERENCES}

1. Гродзинський М.Д. Стійкість геосистем до антропогенних навантажень / М.Д. Гродзинський. - К.: Лікей, 1995. - 233 с.

2. Стійкість екосистем до радіаційних навантажень / I.В. Матвеєва, С.I. Азаров, Ю.О. Кутлахмедов, О.В. Харламова. - К.: НАУ, 2016. - 396 с.

3. Страшкраба М., Гнаук А. Пресноводные экосистемы. Математическое моделирование. Пер. с англ. М.: Мир, 1989. - 376 с.

4. Пригожин И. От существующего к возникающему. Пер. с англ. / Под ред. Ю.Л. Климантовича. - М.: Наука, 1985. - 328 с.

5. Пригожин И. Познание сложного. Введение / Г. Николис, И. Пригожин : пер. с англ. - 2-изд., стер. - М. : Едиториал УРСС, 2003. - 344 с.

6. Пригожин И., Стенгерс И. Порядок из хаоса (Новый диалог человека с природой). М.: изд-во «Едиториал УРСС», 2003. - 310 с.

7. Пригожин, И. Время, хаос, квант : пер. с англ. / И. Пригожин, И. Стенгерс. - М.: Издательская группа «Прогресс», 1999. - 268 с.

8. Хакен Г. Синергетика. Пер. с англ. / Под ред. Ю.Л. Климантовича, С.М. Осовца. М.: Мир, 1980. -404 c.

9. Хакен Г. Синергетика: Иерархия неустойчивостей в самоорганизующихся системах и устройствах : пер. с англ. / Г. Хакен. - М. : Мир, 1985. - 423 с.

10. Владимиров В.А. Управление риском: Риск. Устойчивое развитие. Синергетика / В.А. Владимиров, Ю.Л. Воробьев, С.С. Салов и др. - М. : Наука, 2000. - 431 с.

11. Арнольд В.И. Теория катастроф / В.И. Арнольд. - 3-е изд., доп. - М. : Наука, 1990. $-128 \mathrm{c}$.

Text of the article was accepted by Editorial Team 17.01.2018

\section{С.I. Азаров, О.С. Задунай}

\section{АНАЛІЗ СТІЙКОСТІ ВОДНИХ ОБ'ЄКТІВ ДО ДІЇ ДЕСТАБІЛІЗУЮЧИХ ФАКТОРІВ}

Анотація. Розроблено методичні підходи до оцінки екологічної безпеки екосистем, які базуються на встановленні комплексного показника деградації компонентів природного середовища, що дозволить оцінювати неадитивні властивості різномасштабних водних екосистем. Проведено аналіз методів оцінки стійкості водойм до зміни параметрів природного і антропогенного режимів. Дослідження природи стійкості водних об'єктів виявило не тільки прагнення їх до рівноваги, а й складну боротьбу регулярних та нерегулярних (флуктуацій) сил.

Ключові слова: екосистема; безпека екосистем; стійкість; антропогенні впливи; властивості; параметри; середовище; ентропія.

\section{Автори (науковий ступінь, вчене звання, посада):}

\section{Азаров Сергій Іванович}

доктор технічних наук, старший науковий співробітник, провідний науковий співробітник

Інститут ядерних досліджень НАН України

Адреса робоча: 03680 Україна, м. Київ, пр-т Науки, 47

ORCID ID 0000-0002-9951-8867 e-mail: azarov@kinr.kiev.ua

\section{Задунай Олексій Сергійович}

начальник центру, здобувач наукового ступеня кандидата технічних наук Державний науково-дослідний інститут спеціального зв'язку та захисту інформації Адреса робоча: 03142 Україна, м. Київ, вул. М. Залізняка, 6 ORCID ID 0000-0001-8589-1604 e-mail: a.zadunaj@ gmail.com 